DOI https://doi.org/10.30525/978-9934-26-007-0-4

\title{
ПРАВОВА КОМПЕТЕНЦІЯ В ЗАГАЛЬНОТЕОРЕТИЧНІЙ ЮРИСПРУДЕНЦЇ̈: ПОНЯТТЯ Й ОСОБЛИВОСТІ
}

\author{
Борщевський І. В., Гринь О. Д.
}

\section{ВСТУП}

Швидкий розвиток економічних відносин в Україні досить динамічно змінює систему соціальних і професійних цінностей, це зумовлює переосмислення багатьох традиційних категорій, установлення й обгрунтування появи нових феноменів правової реальності. До таких новітніх категорій відноситься правова компетенція, яка є складником правосвідомості не тільки носіїв спеціальних юридичних знань, а й представників низки професій, які в силу своєї діяльності чітко регламентовані нормами права, більше того, уся їхня діяльність зводиться в основному до реалізації певного алгоритму дій, описаного в нормативному акті.

Зміни, які відбуваються в сучасному соціально-культурному житті суспільства, швидкий плин науково-технічної революції, інформатизованість відносин накладають свої відбитки на освіту й зумовлюють необхідність реформування й перегляду змісту освіти, «підлаштування» його до сучасних вимог і потреб суспільства. Входження України в Європейське освітне середовище, інтеграція національної системи освіти у світову та орієнтація на європейські та світові стандарти, зумовили впровадження до змісту сучасної освіти компетентнісного підходу, сутність якого розкривається через поняття «компетенція» й «компетентність». Однозначності серед науковців щодо трактування цих понять сьогодні немає, відсутні також загальноприйняті дефініції цих термінів.

Компетенція є юридичною характеристикою, за допомогою якої точно фіксується становище певного органу в політико-правовому просторі. İï складові елементи дають змогу максимально чітко визначити правове положення конкретного органу як суб'єкта владних правовідносин.

Як правильно зазначається в юридичній літературі, незалежно від того, $\epsilon$ компетенція повністю самостійною (конкретного органу публічної влади) чи має похідний характер (структурних підрозділів чи посадових осіб), можна говорити про іiі подвійне призначення. Шляхом державно-владного встановлення компетенції чітко фіксується обсяг і зміст діяльності того чи іншого суб'єкта, що здійснює управління. Водночас проводиться розмежування його функцій із функціями інших суб'єктів, що співвідносяться з ним як за «вертикаллю», так і за «горизонталлю», іншими словами, закріплюється певний порядок розподілу всієї сукупності державних функцій, що реалізуються управлінським апаратом. 
Структурно компетенція являє собою сукупність предметів відання й повноважень. 3 метою нормального функціонування, усунення дублювання та правильного поділу праці кожна владна інституція повинна діяти спеціалізовано, тобто в певних сферах суспільних відносин. Така сфера діяльності, у межах якої діє орган, визначається першочергово та юридично закріплюється. У юриспруденції вона дістала назву «предмети відання», під якими розуміють юридично визначені сфери суспільних відносин, у межах яких діє владний суб'єкт.

\section{1. Сутність і наукові підходи до поняття «компетенція»}

Поняття «компетенція» визначається вченими по-різному, але всі трактування мають спільну основу. Для узагальнення думок вчених щодо названого терміна, визначимо основні напрямки його розуміння.

Дослідження проблем і завдань компетентнісного підходу знаходимо в працях В. Байденка, А. Бермуса, І. Зимньої, В. Козирьова, В. Краєвського, Н. Кузьміної, А. Маркової, О. Овчарука, О. Пометуна, Р. Уайта, А. Хуторського й інших. Теоретичному аналізу понять «компетенція», «компетентність» присвячені роботи М. Головань, О. Грішнова, В. Калініна, О. Кучай, Н. Нагорної, В. Лозовецької, Н. Перевознюк, В. Плохій, Г. Руденко, Ю. Тихомирова й інших.

Питання правової компетенції як складника правосвідомості досліджували в працях О. Бучевська, І. Василюк, Ю. Грошевий, О. Губарева, О. Денисова, О. Джура, А. Званчук, Я. Кичук, А. Крижановський, В. Мухін, Ю. Оборотов, В. Царенко.

Однак, незважаючи на певну вивченість цієї проблеми, серед науковців досі триває дискусія щодо визначення змісту й сутності понять «компетенція», «компетентність», установлення їх складових компонентів і взаємного співвідношення. Незважаючи на вимоги наукової методології щодо термінологічної однозначності трактувань понять, у різних наукових працях ці поняття трактуються по-різному: в одних - розрізняються, в інших - ототожнюються.

У трактуванні компетенції спостерігаються різні підходи. Досить часто конкуруючими поняттями $є$ права й обов'язки, повноваження, функції та предмети ведення, юрисдикція, підсудність і підвідомчість. Справді, визначити їх співвідношення між собою за обсягом і змістом складно, до того ж для різних видів суб'єктів. Б. Лазарев, наприклад, розглядає «компетенцію органу управління як його право й обов'язок здійснювати конкретні управлінські функції в певній сфері» ${ }^{1}$.

\footnotetext{
1 Лазарев Б.М. Компетенция органов управления. Москва : Юрид. лит., 1972. С. 11-87.
} 
Адміністративісти (Д. Бахрах) найчастіше включають у поняття компетенції владні повноваження або обов'язки і права та підвідомчість (коло справ) ${ }^{2}$.

На думку Д. Батракової, «компетенція - це система прав і обов'язків, які становлять повноваження органів державної влади та місцевого самоврядування у сфері управління справами місцевого значення та які зумовлені їх цілями, завданнями та функціями» ${ }^{3}$.

Компетенцію як сукупність юридично встановлених повноважень, прав та обов'язків конкретного державного органу чи посадової особи, що визначають його місце в системі державних органів, як правовий засіб (форму) суспільного розподілу праці з управління державою та суспільством характеризують О. Кутафін і К. Шеремет ${ }^{4}$.

«Компетенція - це права та обов'язки органу, якими він наділяється для вирішення тих питань, що становлять предмет його відання», - визначають В. Кравченко та М. Пітцик ${ }^{5}$. Два складові елементи - предмети відання й визначені повноваження - як зміст компетенції виділяє Ю. Тихомиров. Єдиної позиції щодо визначення сутності поняття «компетенція» серед учених немає, що зумовлено складністю самого поняття й різнобічністю елементів, що його характеризують. Загалом основними елементами компетенції є права (повноваження) та обов'язки.

На думку Ю. Потьомкіної, зміст категорії «компетенції» полягає в уявленні для дослідника підстави успішної діяльності. Ці підстави гарантують успіх, у цих гарантіях - сенс застосування компетенцій як категорії межі управлінської діяльності. Компетенції мають універсальний характер, оскільки можуть бути трансформовані в компетентності різних осіб, які відтворені й можна розвивати. Компетенції завжди адресовані конкретному соціальному простору (інституту). Орієнтованість на цей простір задає суб'єкту розуміння його ролі (виконавець, організатор, експерт), формує уявлення про адресата і його очікування. Компетенції завжди конкретні, вони формулюються в термінах завдань і дій, вони відповідають цілям діяльності й допомагають заздалегідь визначити суттєві параметри його результатів. Компетенції використовуються для прогнозування успішної діяльності, оцінювання актуальної діяльності,

\footnotetext{
${ }^{2}$ Бахрах Д.И. Административное право России : учебник для вузов. Москва : Изд. группа НОРМАИНФРА-М., 2000. С. 177-178.

3 Батракова Д. Визначення компетенції місцевих органів державної влади та органів місцевого самоврядування: проблема співвідношення. Юридичний вісник. 2016. № 1. С. 18.

${ }^{4}$ Кутафин О.Е., Шеремет К.Ф. Компетенция местных органов : учебное пособие. Москва, 1996.

${ }^{5}$ Кравченко В.В., Пітник М.В. Конституційні засади місцевого самоврядування в Україні (основи муніципального права) : навчальний посібник. Київ, 2001.
} 
визначення напряму та змісту подальшого навчання й формування професійних та організаційних стандартів ${ }^{6}$.

Незважаючи на те що питання компетенції постійно перебувають у сфері уваги представників юридичної науки, важливість цих питань, ступінь їх складності не дають змоги сформулювати остаточні висновки щодо визначення сутності та змісту компетенції .

Компетентнісний підхід передбачає зміну цілей та очікуваних результатів у вигляді компетенцій, які відображають різні рівні професійних завдань. Результат освіти в контексті компетентнісного підходу розглядається як уміння діяти, застосовувати набуті знання в проблемних ситуаціях професійної діяльності й характеризується поняттям «компетентність» 8

Загальносвітові тенденції розвитку державного управління в умовах глобалізації впливають на масштабність завдань, які доводиться вирішувати в умовах сьогодення. Це цілком стосується й проблеми компетентності державних службовців. В останні десятиліття поняття «компетентність» набуває все більшої популярності. Інтерес до зазначеного питання можна пояснити тим, що в основі дефініції поняття «компетентність» лежить ідея виховання особистості, яка не лише повинна мати необхідні знання, професіоналізм, високі моральні якості, а й уміти діяти адекватно у відповідних ситуаціях, застосовувати знання й брати на себе відповідальність за певну діяльність ${ }^{9}$.

Звідси вагомого значення та визнання набуває компетентнісний підхід як сучасна інноваційна парадигма. Це, безумовно, потребує з'ясування й уточнення сутності ідеї, розробки понятійно-категоріального апарату та відповідного інструментарію впровадження їх у науковий обіг і практику дослідження, а також пошук тих компетенцій, які повинен мати спеціаліст для ефективної професійної діяльності. Особливої гостроти ці питання набувають в освітній сфері. Очевидно, що саме освіта має бути пріоритетною в оновленні знань, удосконаленні вмінь і навичок, а також отриманні нових знань випереджувального характеру, пов'язаних із динамікою сучасних змін.

Компетентнісний підхід як інноваційна парадигма, сучасний напрям пошуку та запровадження тих компетенцій i компетентностей, які повинен мати спеціаліст для ефективної професійної діяльності, є предметом дослідження зарубіжних і вітчизняних учених. Та вперше пов'язані з цим підходом поняття

\footnotetext{
${ }^{6}$ Потьомкіна Ю.С. Компетенція як ключове поняття для управління персоналом у системі державної служби. Економіка та держава. 2013. № 4. С. 133-134.

${ }^{7}$ Кулакова Є.В. Поняття та елементи господарської компетенції обласних рад та обласних державних адміністрацій. Науковий вісник Міжнародного гуманітарного університету. Серія «Юриспруденція». 2013. Вип. 6-2 (2). С. 19.

${ }^{8}$ Кобзар Н.В. Поняття «компетентність», «компетенція» і «готовність до діяльності» в сучасній освітній парадигмі. Науковий вісник Донбасу. 2010. № 3. С. 12-17.

${ }^{9}$ Клепко С.Ф. Філософія освіти в Європейському контексті. Полтава : ПОІППО, 2006. С. 234.
} 
набули характеру операціональної характеристики успішної професійної діяльності в теоретичних розробках американських дослідників. Так, зокрема, Річард Бояцис у працях визначає типи, рівні та моделі компетенцій ${ }^{10}$, Лайл М. Спенсер, Сайн М. Спенсер - моделі компетенцій максимально ефективної роботи $^{11}$. Напрацювання англійського вченого Дж. Равена присвячені особливостям компетенції різних професійних груп ${ }^{12}$.

Разом із тим поділяємо точку зору Н. Бібік, яка зазначає, що процес роботи в Україні за компетенціями лише розпочався й потребує глибокого та всебічного опрацювання ${ }^{13}$.

3 огляду на це, подальше дослідження теоретико-методологічних основ компетентнісного підходу, пошук нових форм i механізмів його запровадження, які були б адекватні вимогам сучасності й завданням конкретної соціальної сфери, доречно починати 3 категоріального аналізу понять «компетентність» і «компетенція».

Загальновідомо, що введення кожного нового поняття в науковий обіг потребує його обгрунтування, тлумачення. Проведення певного наукового узагальнення дає можливість констатувати, що сучасні науковці по-різному підходять до визначення понять «компетентність» і «компетенція». Одні автори вживають ці терміни як синоніми, інші їх розрізняють. Тож для подальшого з'ясування сутності зазначених категорії доцільним уважаємо звернутися передусім до словників.

Так, у Великому тлумачному словнику сучасної української мови знаходимо доволі схожі визначення цих понять. Зокрема, компетенція - це: 1) добра обізнаність із чим-небудь; 2) коло повноважень якої-небудь організації, установи чи особи; компетентний - це: 1) який має достатні знання в якій-небудь галузі, який з чим-небудь добре обізнаний, тямущий; який грунтується на знанні, кваліфікований; 2) який має певні повноваження, повноправний, повновладний ${ }^{14}$.

У Словнику іншомовних слів ці поняття дещо розрізняються: перше тут трактується як коло питань, у яких особа має знання, досвід; друге - як поінформованість, обізнаність, авторитетність ${ }^{15}$. У контексті цього розгляду

\footnotetext{
${ }^{10}$ Бояцис Р. Компетентный менеджер. Модель эффективной работы / пер. с анг. Москва : ГИППО, 2008. C. 126 .

11 Лайл М., Спенсер. Компетентность на работе. Модели максимальной эффективности / пер. с англ. Москва : НІРPO, 2005. С. 212.

12 Равен Дж. Компетентность в современном обществе: выявление, развитие и реализация / пер. с англ. Москва : Когито-Центр, 2002. С. 117.

${ }^{13}$ Бібік Н. Компетентнісний підхід презентації освітніх результатів. Школа першого ступеня: теорія $i$ практика : збірник наукових праць ; Переяслав-Хмельницького держ пед. ун-ту ім. Григорія Сковороди. Переяслав-Хмельницький, 2004. Вип. 10. С. 88.

${ }^{14}$ Великий тлумачний словник сучасної української мови / уклад. і гол. ред. В.Т. Бусел. Київ, Ірпінь : ВТФ «Перун», 2001. С. 98.

${ }^{15}$ Словарь иностранных слов. 14-е изд., испр. Москва : Рус. яз., 1987. С. 75.
} 
вважаємо за доцільне навести визначення поняття «компетентність» як: 1) досвідченість у певній галузі, якомусь питанні; повноправність у розв'язанні якоїсь справи; поінформованість, обізнаність; авторитетність; коло повноважень (прав і їхніх обов'язків) певного органу чи посадової особи, установлених статутом (або іншими положеннями) установи, закладу; 2) спроможність кваліфіковано проводити діяльність, виконувати завдання або роботу. При цьому поняття компетентності містить набір знань, навичок і ставлень, що дає змогу особистості ефективно діяти або виконувати певні функції, спрямовані на досягнення стандартів у професійній галузі або певній діяльності ${ }^{16}$.

Аналіз позицій учених щодо осмислення сутності понять «компетенція» й «компетентність» дає підстави стверджувати про їх багатозначність i багатогранність. Усе це створює передумови для існування різних наукових підходів до розуміння сутності понять. Зупинимося на деяких із них.

Так, перший підхід у визначені понять пов'язаний 3 їх значенням у забезпеченні зв'язку теоретичних і практичних складників освіти. Його прихильники вбачають у компетенціях зв'язок, який дає змогу практично застосовувати набуті знання (П. Борисов, І. Родигіна, О. Савченко, М. Чошанов). Тож, підсилюючи практичну значущість сутності поняття, П. Борисов визначає компетентність як здатність застосовувати отримані знання й уміння на практиці, у житті для розв'язання проблем ${ }^{17}$.

Компетенція актуалізує прагматичну спрямованість освітнього процесу, тоді як компетентність доповнюється особистими якостями індивіда (мотиваційними, вольовими, етичними, ціннісними оріснтаціями, звичками тощо). При цьому важливість їх взаємодії полягає в тому, що компетентність $€$ проявом компетенції.

У комплексних дослідженнях проблематики чітко простежується другий підхід, у якому компетентність розглядається як оцінна категорія. Зокрема, Н. Бібік зазначає, що «компетенції» сприймаються як похідні, вужчі від «компетентності». Зокрема, вона наголошує, що аналіз контексту вживання поняття «компетенції» дає змогу розуміти його як соціально закріплений освітній результат. Тобто компетенції можуть бути виведені як реальні вимоги до засвоєння сукупності знань, способів діяльності, досвіду, ставлень, якостей особистості, яка діє в соціумі ${ }^{18}$.

\footnotetext{
16 Компетентнісний підхід у сучасній освіті: світовий досвід та українські перспективи: Бібліотека 3 освітньої політики / за заг. ред. О.В. Овчарук. Київ : К.І.С., 2004. С. 67.

${ }^{17}$ Борисов П.П. Компетентностно-деятельностный подход и модернизация содержания общего образования. Стандарты и мониторинг в образовании. 2003. № 1.

${ }^{18}$ Бібік Н. Указ. соч. Школа першого ступеня: теорія і практика : збірник наукових праць ПереяславХмельницького держ пед. ун-ту. С. 46.
} 
Як уже зазначалося, компетентність є ступенем або рівнем здатності особистості ефективно діяти. Оскільки, за дослідженнями П. Борисова, кожний вид компетентності має різні рівні освоєння (мінімальний, достатній i високий ${ }^{19}$, оцінка компетентності повинна даватися відповідно до певних державних стандартів чи критеріїв якості. Компетентність же має відповідати рівню, прийнятому в професійній галузі або у сфері діяльності.

Зважаючи на те що поняття «компетентність» є системним утворенням, російські вчені В. Краєвський та А. Хуторський визначили ще один науковий підхід. За їхніми дослідженнями, компетентність - це сукупність особистісних якостей людини (ціннісно-смислових орієнтацій, знань, умінь, навичок, здібностей), які зумовлені досвідом іiі діяльності в певній соціальній та особистісно значущій сфері ${ }^{20}$.

А. Хуторський, зокрема, розглядає компетентність як оволодіння людиною відповідною компетенцією, включаючи іiї особистісне ставлення до неї й до предмета діяльності. Варто згадати, що російський дослідник складниками компетенції вважає сукупність взаємопов'язаних якостей особистості (смислових орієнтацій, знань, умінь, навичок і досвіду діяльності), необхідних для здійснення особистісно й соціально значущої продуктивної діяльності щодо об’єктів реальної дійсності Він також уточнює, що під компетенцією варто розуміти наперед задану вимогу (норму) до освітньої підготовки особистості, а під компетентністю - уже особистісну якість (сукупність якостей), які вже сформовано, а також мінімальний досвід щодо певної діяльності. Тобто компетентність передбачає мінімальний досвід застосування компетенції ${ }^{21}$.

Підхід до сутності компетентності як сукупності особистісних якостей людини дає змогу оцінити ці якості, визначити їх природу й цінність для неї. Таке тлумачення компетентності засвідчує, що людина не засвоює окремо знання й уміння, а оволодіває комплексною процедурою, к якій для кожного виділеного напряму характерна відповідна сукупність компонентів, що мають особистісно-діяльнісний характер.

Нарешті, важливим $є$ й інший підхід до з'ясування змісту понять «компетенція» i «компетентність», який характеризується тим, що вони визначаються через категорії «здатність», «готовність», «здібність». Прихильниками цього підходу є чимало зарубіжних і вітчизняних учених, а саме: О. Дахін, I. Срмаков, В. Краєвський, В. Кальней, О. Овчарук, О. Пометун, М. Рибаков, С. Шишов, Дж. Равен.

\footnotetext{
${ }^{19}$ Борисов П. П. Указ. соч. Стандарты и мониторинг в образовании. 2003.

20 Краевский В.В., Хуторский А.В. Предметное и общепредметное в образовательных стандартах Педагогика. 2003. № 2. С. 23.

21 Хуторской А.В. Ключевые компетенции как компонент личностно-ориентированной парадигмы образования. Нар. образование. 2003. № 3. С. 34 .
} 
Так, С. Шишов розглядає компетенцію як загальну здатність, яка грунтується на знаннях, досвіді, цінностях, схильностях, набутих завдяки навчанню. Зіставляючи уміння й компетенції, він зазначає, що компетенція породжує вміння, дію22.

О. Дахін визначає компетенцію як сферу діяльності або коло питань, уяких людина професійно обізнана, володіє системними знаннями та великим досвідом роботи. Він розглядає компетентність у певній галузі як наявність у людини необхідних знань і здібностей, які дають змогу аналізувати, робити висновки й приймати ефективні рішення, а також раціонально діяти, реалізуючи вказані рішення ${ }^{23}$.

$\mathrm{y}$ найзагальнішому вигляді компетенція $\epsilon$ комплексом легально встановлених способів здійснення публічних функцій. Вона складається 3 елементів двоякого роду. Проаналізувавши структуру компетенції, необхідно відмітити, що до власне компетенційних елементів відносяться предмети відання як юридично-певні сфери й об'єкти впливу, так і владні повноваження як гарантована законом міра прийняття рішень. До супутніх елементів варто віднести передусім цілі як довгострокову нормативну орієнтацію, що виражається в безперервному вирішенні завдань, що виникають, за допомогою здійснення компетенції. Таким $є$ й обов'язок діяти стосовно держави або її органів і посадових осіб. Без неї компетенція втрачає головне - публічно-правове забезпечення за допомогою різних засобів.

Системний підхід до компетенції виражається в такому розумінні іiі суб'єктів, коли вони взаємодіють між собою в процесі виконання державних, регіональних та інших завдань. Держава як керуюча система володіє суверенітетом і виконує публічні функції. Часто говорять про управління державними справами. У міжнародно-правовому плані мова йде про юрисдикції суверенної держави на своїй території й повноваження міжнародних і міждержавних об’єднань, похідних від державного суверенітету.

Компетенцію мають усі державні інститути й органи - Президент, парламент, Уряд, міністерство, губернатор тощо. Для виконавчої влади особливе значення має чіткий розподіл повноважень усередині ії ланок ${ }^{24}$.

Ю. Тихомиров зазначив, що правильному розумінню компетенції сприяє iï загальноправове трактування. Це - базове поняття публічного права, що визначає життєдіяльність не тільки суб'єктів публічно-правових, а й приватноправових відносин. Воно визнається й установлюється насамперед нормами конституційного, адміністративного, фінансового, кримінального

\footnotetext{
${ }^{22}$ Шишов С.Е. Понятие компетенции в контексте качества образования. Стандарт и мониторинг в образовании. 1999. № 2. С. 28.

${ }^{23}$ Стратегія реформування освіти в Україні : рек. з освітньої політики. Київ : К.І.С., 2003.

24 Васильева Л.Н. Взаимоотношения федеральных и региональных органов государственной власти: пути совершенствования. Журнал российского права. 2000. № 8.
} 
та міжнародного публічного права. Компетенція визначається переважно в статутних i тематичних законах та інших актах (положеннях тощо). Реалізується ж компетенція 3 допомогою норм усіх галузей права, і це міркування вважається важливим для правозастосовної практики.

Умілий порівняльно-правовий аналіз компетенцій дуже корисний у науковому та практичному плані. Аналіз досвіду іноземних держав дає змогу помітити, по-перше, велику роль конституційних основ компетенції; по-друге, забезпечення більш самостійних повноважень органів і менший ступінь їх суміжних дій з іншими органами; по-третє, гнучке поєднання загальних повноважень держави і статутних повноважень ії органів ${ }^{25}$.

Так, у науковій літературі існують такі визначення компетенції:

1) компетенція (лат. competentia - належність за правом) - коло повноважень будь-якого органу або посадової особи та коло питань, у яких ця особистість має знання, досвід ${ }^{26}$;

2) компетенція (лат. competentia, від compete - взаємно прагну; відповідаю, підходжу) - сукупність предметів відання, завдань, повноважень, прав та обов'язків державного органу або посадової особи, що визначаються законодавством ${ }^{27}$;

3) сукупність предметів відання й повноважень (прав та обов'язків), які надаються суб'єкту управління (органу або посадовій особі) для виконання відповідних завдань і функцій і визначають його місце в апараті державного управління. Компетенція державно-владним шляхом установлює обсяг i зміст діяльності суб'єкта державного управління з одночасним розмежуванням його функцій і функцій інших суб'єктів як по вертикалі, так і по горизонталі управлінської системи ${ }^{28}$;

4) установлена нормами Конституції та законів України сукупність прав, обов'язків і предметів відання органів виконавчої влади та їх посадових, службових осіб, які забезпечують здійснення функцій і завдань виконавчої влади;

5) компетенція державного органу (уряду, міністерства, парламенту, органів суду, міліції, прокуратури та ін.) - закріплена законом (або іншим нормативним актом) сукупність владних повноважень (прав та обов'язків), юридичної відповідальності й предмета відання (предмет діяльності, функціональне призначення) ${ }^{29}$;

\footnotetext{
25 Тихомиров Ю.А. Теория компетенции. Журнал российского права. 2000. № 10. С. 24-26.

${ }^{26}$ Словарь иностранных слов. 18-е изд., стер. Москва : Рус. яз., 1989. С. 247.

${ }^{27}$ Словник іншомовних слів / за ред. О.С. Мельничука ; головна ред. Української радянської енциклопедії Академії наук Української РСР (АН УРСР). Київ : АН УРСР, 1974. С. 302.

${ }^{28}$ Малиновський В.Я. Словник термінів і понять 3 державного управління. 2-ге вид., допов. і виправл. Київ : Центр сприяння інституц. розвитку держ. служби, 2005. С. 87.

${ }^{29}$ Скакун О. Ф. Теорія держави і права : підручник / пер. з рос. Харків : Консум, 2001. С. 87.
} 
6) компетенція посади державної служби - це окреслене коло проблем, що належать до повноважень, прав та обов'язків за певною посадою і окреслюють вимоги до кадрів для виконання ними посадових функцій.

Проводячи дослідження сутності й видів компетенції органів публічної влади, варто зупинитися на їх правовій компетенції. Так, компетенція суб'єктів публічної служби завжди більш чітко закріплена в правовому полі, ніж функції, які лише частково визначені правовими нормами. Компетенція визначає обсяг і зміст діяльності суб'єкта; здійснює розмежування функцій з іншими суб'єктами; забезпечує певний розподіл функцій, які реалізуються публічною службою загалом; установлюється за ієрархічним принципом або волею народу за виборним принципом.

Компетенція органів публічної влади - це сукупність закріплених у нормативно-правових актах предметів відання, які мають визначатися чіткими формулюваннями, точним напрямком публічного управління, конкретними завданнями, що загалом становить цілі та мету діяльності органів публічної влади. Функції органів публічної влади виявляються саме через сукупність усіх елементів їх компетенції.

Предмети відання як складники компетенцій органів місцевого самоврядування в сучасних децентралізаційних процесах потребують i чіткого визначення на національному рівні, і нормативного врегулювання, і врегулювання питань їх реалізації безпосередньо на місцевому рівні ${ }^{30}$.

Науковці та практики у сфері публічного управління зазначають про необхідність закріплення на конституційному рівні положення, що місцеве самоврядування $\epsilon$ визнаним і гарантованим державою правом і реальною спроможністю територіальної громади самостійно, у власних інтересах і під свою відповідальність або відповідальність органів і посадових осіб місцевого самоврядування вирішувати питання місцевого значення на підставі й у межах Конституції та законів України ${ }^{31}$.

Окрема увага дослідників прикута до питань розмежування компетенцій органів публічної влади 3 позиції права (адміністративного, конституційного), теорії (публічного управління, політології), методологічних розробок (механізмів, методів, інструментів тощо). Тому аналіз досліджень щодо цієї проблематики доцільно формувати комплексно, 3 урахуванням усіх складників компетенцій органів публічної влади, їх взаємозв'язку 3 предметом діяльності (чи предметом відання, про що йтиметься далі), об'єкта

\footnotetext{
${ }^{30}$ Карпа М.І. Визначення предметів відання як складових компетенцій органів місцевого самоврядування. Публічне управління: ціннісні орієнтири, стандарти якості та оцінка ефективності : матеріали Всеукраїнської наук.-практ. конференції за міжнар. участю (м. Київ, 26 травня 2017) / Національна академія державного управління при Президентові України. Київ, 2017.

${ }^{31}$ Батанов О. Проблеми конституційної регламентації компетенції місцевого самоврядування в Україні та зарубіжних країнах. Право Украӥни. 2015. № 9. С. 111.
} 
управління (у площині теорії публічного управління). Питання компетенції органів публічної влади розкриті О. Сушинським у сфері комунальних послуг ${ }^{32}$. Дослідник також розглядає питання статусу як передумови до діяльності органів публічної влади в контексті розкриття основних складників їх компетенції, зокрема відповідальності ${ }^{33}$.

Широкого вжитку у сфері правової освіти набуло поняття «правова предметна компетенція», установлено перелік (когнітивна, аксіологічна, практично-поведінкова) та сутність правових предметних компетенцій ${ }^{34}$. Окремі дослідження розкривають спеціальні компетенції в контексті спеціальних статусних характеристик органів публічної влади ${ }^{35}$.

Загальна компетенція зафіксована здебільшого в нормативному полі загальними положеннями. Основні повноваження та функції органів публічної влади визначаються Конституцією або/та законами. У частині 2 ст. 19 Конституції України визначено, що «органи державної влади та органи місцевого самоврядування, їх посадові особи зобов'язані діяти лише на підставі, у межах повноважень та у спосіб, що передбачені Конституцією та законодавчими актами» ${ }^{36}$. Суб'єкти публічної служби мають право вирішувати будь-яке питання, яке не вилучене зі сфери їхньої компетенції. Деякими науковцями до сфери загальної компетенції обласних державних адміністрацій варто віднести питання контролю за дотриманням законодавства, організацію заходів загальнодержавного спрямування. За органами місцевого самоврядування варто закріпити функції надання громадських послуг, задоволення культурних, освітніх та інших потреб населення ${ }^{37}$.

Визначення та реалізація компетенцій органів публічної влади за предметною ознакою базується за предметами відання, утвердженими в нормативному

\footnotetext{
32 Сушинський O.I. Компетенція держави та місцевого самоврядування у сфері комунальних послуг: концепція та практика : монографія. Львів : ЛРІДУ НАДУ, 2005.

${ }_{33}$ Сушинський O.І. Місцеві державні адміністрації: статус і організація діяльності : монографія. Львів : ЛРІДУ НАДУ, 2012.

Сушинський O.I. Правоохоронні органи України: проблемні аспекти статусу : монографія. Львів : Львівський державний інститут новітніх технологій та управління імені В'ячеслава Чорновола, 2010.

Сушинський О I. Юридична відповідальність у контексті демократизації публічної влади. Демократичні засади державного управління та адміністративне право : монографія / кол. авт. : Ю.С. Шемшученко, В.Б. Авер'янов, О.Ф. Андрійко та ін. ; за заг. ред. д. ю. н. В.Б. Авер'янова. Київ : Юридична думка, 2010. С. 300-306.

${ }^{34}$ Рябовол Л.Т. Правова предметна компетентність: поняття, структура, правові предметні компетенції. Наукові записки КДПУ. Серія «Педагогічні науки»/ ред кол.: В.В. Радул та ін. Кіровоград : КДПУ ім. В. Винниченка, 2013. Вип. 121. Ч. 2. С. 263-268.

${ }^{35}$ Кушнір І.П. Проблемні питання відомчої нормотворчої компетенції прикордонної служби України. Молодіжний науковий юридичний форум : матеріали Всеукраїнської науково-практичної конференції до Дня науки, м. Київ, Національний авіаційний університет, 18 травня 2017 р. Тернопіль : Вектор, 2017. Том 1.

${ }^{36}$ Конституція України: прийнята на п’ятій сесії Верховної Ради України 28.06.1996. Biдомості Верховної Ради Украӥни. 1996. № 30. Ст. 141.

${ }^{37}$ Майстро С.В. Розмежування повноважень органів державної влади та органів місцевого самоврядування. Державне будівнищтво. 2012. № 1. URL: http://nbuv.gov.ua/UJRN/DeBu_2012_1_33.
} 
полі, на основі яких відбувається визначення повноважень, тобто прав та обов'язків. Отже, предметний складник у компетенції органів публічної влади знаходиться в площині визначення та закріпленні предметів відання. Передумовою до формування предметної компетенції є загальна компетенція, що зазвичай визначається на конституційному рівні або/та законами.

Передумовою визначення загальної компетенції органів публічної влади $\epsilon$ їхні основні функції та завдання. Тобто в запропонованій схемі «функція компетенція - статус - діяльність» зображено послідовність утвердження для застосування компетенційного підходу в діяльності органів публічної влади та закладено основу для подальшої розробки теоретико-методологічної бази в практиці діяльності органів публічної влади.

Предмети відання розкриті в роботі як основа для аналізу предметної компетенції, як основний напрям діяльності, що проявляється у функціях і функціональному призначенні органів публічної влади. Предмети відання багатьох суб'єктів перетинаються, що є цілком прийнятним і логічним, але їхні повноваження $\epsilon$ виключно індивідуальними, навіть коли функція декількох суб'єктів є загальною для всіх. Під предметом відання місцевого самоврядування розуміються сфери місцевого життя, у межах яких діє передбачений законом, а отже, і юридична компетентний у них орган. Отже, предмет відання як структурний елемент категорії компетенція є способом юридичного зазначення тих сфер місцевого життя, які визначаються як предмет дій органу місцевого самоврядування.

Правознавство визначає встановлення підвідомчості як розмежування компетенції між органами (посадовими особами). Підвідомчість - це юридична вказівка на коло суспільних публічно-правових відносин, повноправним суб'єктом яких є конкретний суб'єкт. Щодо взаємозв'язку територіального показника як одного із засобів (поряд 3 предметами відання) 3 компетенцією органів публічної влади для визначення сфери суспільних відносин, повноважним суб'єктом яких $\epsilon$ конкретний орган і розмежування компетенції органів, що виконують однорідні функції, мають рівний правовий статус або тотожні повноваження в однорідних за змістом правовідносинах, доцільним видається виокремлення територіальної компетенції.

На підставі здійсненого дослідження окреслено низку проблем у розробці поняття предметної компетенції органів публічної влади. Серед них зазначено визначення питань державного та місцевого значення, закріплення їх у нормативному полі; здійснення розмежування компетенцій органів публічної влади на місцевому рівні; розподіл функцій органів публічної влади; питання визначення й урахування публічного інтересу в діяльності органів публічної влади ${ }^{38}$.

\footnotetext{
${ }^{38}$ Карпа М. Предметна компетенція органів публічної влади. Актуальні проблеми державного управління. 2017. Вип. 3. С. 50-56.
} 
Оновлення системи державного управління, якого сьогодні вимагає суспільство, не може відбуватися без змін у ії організаційному й функціональному складниках. Тобто реформа має охопити як кількість, структуру та ієрархічну побудову інституцій державної влади, так i функції цих інституцій, їх структурних підрозділів та окремих державних службовців. При цьому особливу увагу необхідно звернути на обсяг прав, обов'язків і повноважень, які інституції державного управління та державні службовці використовують для виконання своїх функціональних завдань. Отже, реформа державного управління в Україні стосуватиметься й реформи державно-управлінських компетенцій. Тому варто ще раз проаналізувати сутність і зміст цього поняття, щоб зрозуміти важливість першочергових змін функціонального складника системи державного управління.

Як стверджують автори зарубіжного словника з управління персоналом, поняття «компетентність» позначає не тільки та не стільки наявність i значний обсяг знань і досвіду, скільки вміння їх актуалізувати в потрібний час і використовувати в процесі реалізації своїх службових обов'язків. Наявність у працівника компетентності нічого не вартує без наявності компетенції, яка охоплює сукупність повноважень, прав та обов'язків посадової особи чи суспільної організації.

Фактично термін «компетенція» вживається на позначення пов'язаних із посадою повноважень, а термін «компетентність» - на позначення рис $\mathrm{i}$ якостей людини, яка займає цю посаду. У такому разі на формування компетенції впливають соціальне замовлення, рівень розвиненості суспільства та його окремих представників, конкретно-історичні цілі тощо. На формування компетентності, окрім розглянутих чинників, впливають також компетенція й особистісно-морально-ділові риси суб'єкта ${ }^{39}$.

I компетентність, і компетенція тісно пов'язані 3 адміністративним капіталом. Проте якщо компетентність більшою мірою стосується особи державного службовця, то компетенція - його посади. Тобто разом із адміністративним капіталом передається не компетентність, а компетенція. Відповідно, і формування цієї форми капіталу має відбуватися з урахуванням компетенції державного службовця та державної інституції, у якій він працює або планує працювати.

До державно-управлінської компетенції відносимо компетенцію державних інституцій і компетенцію державних службовців. У понятті «компетенція державної інституції» виявляється спеціальна правосуб'єктність державної інституції як колективного суб’єкта правовідносин. Установлюючи

\footnotetext{
${ }^{39}$ Недашківська Т. Професійність державних службовців: компетентнісний підхід. Наук. пр. Нац. акад. держ. упр. при Президентові України / редкол. : О.Ю. Оболенський (голов. ред.), С.В. Сьомій та ін. Київ : Вид-во НАДУ, 2008. Вип. 1. С. 70-71.
} 
компетенцію кожної інституції, держава здійснює не лише «поділ праці» між ними, а й поділ державно-владних повноважень.

Компетенція державних інституцій - це базове поняття публічного права, що визначає життєдіяльність суб'єктів не лише публічно-правових, а й приватноправових відносин. Ї̈̈ визнають і встановлюють передусім нормами конституційного, адміністративного, фінансового, кримінального та міжнародного публічного права. Компетенцію визначають переважно в статутних i тематичних законах та інших актах (положеннях), а реалізують за допомогою норм усіх галузей права ${ }^{40}$.

Компетенцію державної інституції (уряду, міністерства, парламенту, судових органів, поліції, прокуратури тощо) розуміють як закріплену законом (або іншим нормативним актом) сукупність його владних повноважень (прав та обов'язків), юридичної відповідальності й предмета відання (предмет діяльності, функціональне призначення) ${ }^{41}$. Автор цього положення виокремлює в кожної юридичної особи два блоки компетенції: перший блок становить іiі правосуб'єктність як юридичної особи некомерційної або комерційної; другий блок - спеціальна компетенція, що полягає в праві в певних межах проводити професійну діяльність ${ }^{42}$.

Інший складник компетенції державної інституції - владні повноваження - вимагає додаткового пояснення в контексті того, що наявність прав часто трактують як свободу бачення їх використання. Водночас структури й інституції, наділені повноваженнями, наділені також обов'язками щодо їх здійснення. Об'єднання прав та обов'язків державних інституцій у формі їхніх повноважень діє як правообов'язок, що не можна не реалізувати в суспільних інтересах ${ }^{43}$. Це дає змогу підтримувати наступність влади, управління та правового порядку.

Асоціативним семантичним полем поняття «повноваження», за результатами проведеного серед державних службовців і посадових осіб місцевого самоврядування вільного асоціативного експерименту, $\epsilon$ обов'язки, права, відповідальність, влада, компетенція, компетентність, функція та завдання. Таке усвідомлення суб'єктами управління змісту цього поняття відповідає його термінологічному тлумаченню як конкретних прав, що характеризуються правом та обов'язком здійснювати певні посадові

40 Тихомиров Ю.А. Современное публичное право : монограф. учеб. / Ин-т законодательства и сравнительного правоведения при Правительстве Российской Федерации. Москва : ЭКСМО, 2008. С. 191.

41 Лазор О., Хорошенюк О.В. Публічна служба в Україні: компетенції та повноваження (Частина II) : монографія. Хмельницький : Вид-во ХГПА, 2009. С. 14.

42 Гогіна Л.М. Компетенції та компетентності в державній службі України: до проблеми понятійного апарату. Державне управління: теорія та практика : електрон. наук. фах. вид. / редкол. : С.В. Сьомій (голов. ред.), В.М. Князев та ін. Київ : Вид-во НАДУ 2007. № 2 (6). URL: www.nbuv.gov.ua/e-journals/dutp/2007-2.

43 Лазор О.Я., Хорошенюк О.В. Публічна служба в Україні: компетенції та повноваження (Частина II) : монографія. Хмельницький : Вид-во ХГПА, 2009. С. 17. 
обов'язки й наявністю адміністративних функцій, що дає змогу здійснювати завдання інституції державної влади. Водночас працівники бюджетної сфери сприймають повноваження як атрибут чужої професії, здебільшого пов'язаної 3 керуванням і керівними посадами, й асоціюють його 3 керівником, депутатом, начальником і можливостями. Така ситуація може завадити процесу їхнього спілкування з представниками державної влади.

Юридичні повноваження (правообов'язки) державної інституції чи іiі посадової особи - це вид і спосіб владного впливу на учасника правових відносин із метою реалізації припису правової норми, досягнення певного соціально корисного результату. Юридичні повноваження не можуть бути представлені лише як одне право або лише один обов'язок. 3 одного боку, під час здійснення повноважень державною інституцією та посадовими особами центр ваги у співвідношенні прав та обов'язків припадає на обов'язки, оскільки за їх невиконання настає юридична відповідальність. 3 іншого боку, державна інституція та посадові особи мають право вимагати відповідної поведінки від інших інституцій та осіб, а також їх невтручання усферу своєї компетенції, що встановлена державою. Тому юридичні повноваження постають як певні правообов'язки (поєднання прав та обов'язків). Покладені обов'язки виконують через надані права. Формулюючи повноваження, законодавець в одних випадках може перенести центр ваги лише на права, в інших - лише на обов'язки ${ }^{44}$.

Компетенція державних інституцій має спеціальний характер i не $є$ однаковою для всіх інституцій держави. Порядок установлення й обсяг компетенції залежать від того, до якої ланки державного апарату належить державна інституція - законодавчої, виконавчої, судової гілки влади, органів прокуратури тощо.

На відміну від індивідуальних суб'єктів, правовий статус колективних суб'єктів - державних інституцій як суб'єктів правовідносин обмежено тими цілями та завданнями, заради яких їх створено. Специфіка виконання повноважень державними інституціями полягає в тому, що вони діють у підсистемі публічного права (конституційного, адміністративного права), для якого характерний імперативний метод - юридичної субординації та підпорядкованості. 3 одного боку, це питання компетенції державних інституцій, які мають повноваження на видання в односторонньому порядку індивідуального розпорядження з визначенням прав та обов'язків підпорядкованих і підзвітних осіб, а 3 іншого - питання пасивної правосуб'єктності підпорядкованих і підзвітних осіб, їхніх обов'язків і відповідальності.

\footnotetext{
44 Лазор О.Я., Хорошенюк О.В. Публічна служба в Україні: компетенції та повноваження (Частина II) : монографія. Хмельницький : Вид-во ХГПА, 2009. С. 15.
} 
Обсяг компетенцій конкретних державних інституцій залежить від місця, яке посідає та чи інша інституція в ієрархічній структурі відповідних інституцій: чим вищий рівень інституції, тим більший обсяг їхньої компетенції. За своїм змістом і спрямованістю компетенція державних інституцій відрізняється залежно від гілки державної влади, до якої належить відповідна інституція. Наприклад, парламент наділено широкою законодавчою компетенцією, межі якої не встановлено, а лише окреслено взірцевий обсяг законодавчої діяльності та названо базові закони. В інших сферах діяльності повноваження парламенту визначено більш конкретно. Натомість предметну юрисдикцію судів чітко встановлено в законах і процесуальних кодексах.

Складнішою $€$ характеристика компетенції виконавчих інституцій державної влади. Установлена мета позначає спосіб діяльності нормативної орієнтації суб'єктів права та стійку діяльність для досягнення цієї мети. Ідеться про суспільні функції, без виконання яких неможливо забезпечити життєдіяльність суспільства та держави.

Це - політичні, економічні, соціальні, екологічні й міжнародні функції, кожна з яких має своє «наповнення та виміри».

Основною формою реалізації державними інституціями своєї компетенції $\epsilon$ видання ними правових (нормативних) та індивідуальних актів, а посадовими особами - здійснення організаційно-розпорядчих дій щодо підлеглих їм суб'єктів ${ }^{45}$.

Компетенцію державних службовців визначають цілями та завданнями управлінської діяльності. Компетенція залежить від призначення державної інституції, його місця в системі державного управління, а статус державного службовця - від посади, яку він обіймає. Компетенція окремих державних службовців, наприклад голів місцевих державних адміністрацій, визначена законодавчими актами. Однак, як правило, компетенцію державних службовців визначають у положенні про управління (відділ, сектор, інспекцію, службу) та посадових інструкціях, розроблених на основі типових професійно-кваліфікаційних характеристик посад державних службовців.

На формування компетенції державного службовця впливають соціальне замовлення, рівень розвиненості суспільства та його окремих представників, конкретно-історичні цілі тощо. За умови невідповідності компетентності державного службовця його компетенції виникає конфліктна ситуація.

У науковому середовищі на позначення компетенції державних службовців уживають поняття «компетенція посади державної служби», яке вітчизняна дослідниця Л. Гогіна розуміє як окреслений обсяг проблем, що належать до повноважень, прав та обов'язків за певною посадою й

\footnotetext{
45 Великий енциклопедичний юридичний словник / за ред. акад. НАН України Ю.С. Шемшученка. Київ : Юрид. думка, 2007. С. 373.
} 
окреслюють вимоги до кадрів для виконання ними посадових функцій 46 У Законі України «Про державну службу» поняття «посада» тлумачиться як визначена структурою та штатним розписом первинна структурна одиниця державної інституції та іiі апарату, на яку покладено встановлене нормативними актами коло службових повноважень ${ }^{47}$.

Основними критеріями класифікації посад державних службовців $є$ організаційно-правовий рівень інституції, яка приймає їх на роботу, обсяг i характер компетенції на конкретній посаді, роль і місце посади в структурі державної установи. В Україні встановлено сім категорій посад службовців. Зрозуміло, що вища посада надає більшу компетенцію.

Отже, аналіз вітчизняних і зарубіжних досліджень свідчить, що сутність і зміст поняття «компетенція» потребують подальшого уточнення в контексті реформування системи державного управління. Насамперед це стосується відповідності повноважень завданням, що будуть покладені на оновлений інститут державного управління, і відповідальності державних інституцій і державних службовців. Однак уже сьогодні можна стверджувати, що під час формування компетенції в системі державного управління має бути врахований іiі зв'язок із компетентністю та професіоналізмом осіб, які будуть нею володіти ${ }^{48}$.

\section{2. Зміст і види правової компетенції}

Загалом проблема ефективності організації влади $\epsilon$ надзвичайно складною, різні наукові доктрини пропонують різні шляхи іiі досягнення. Наприклад, економічна теорія федералізму, яка базується на аналізі пропозиції послуг, оцінює іiі з урахуванням таких факторів, як близькість (дає можливість із мінімальними витратами визначити потреби громадян i пропозиції щодо обсягу послуг), ефект надлишків (оптимальний розподіл повноважень досягається тоді, коли всі блага приносять користь лише членам тієї громади, яка їх виробляє), економія на масштабах виробництва (мірою зростання вироблених обсягів зменшуються витрати).

У національному законодавстві України й у вітчизняній юридичній літературі термін «компетенція» застосовується, як правило, для характеристики сукупності юридичних (тобто таких, які визначені в законі) предметів відання, прав та обов’язків органу публічної влади.

\footnotetext{
${ }^{46}$ Гогіна Л.М. Компетенції та компетентності в державній службі України: до проблеми понятійного апарату. Державне управління: теорія та практика : електрон. наук. фах. вид. / редкол. : С.В. Сьомій (голов. ред.), В.М. Князев та ін. Київ : Вид-во НАДУ 2007. № 2(6). URL: www.nbuv.gov.ua/e-journals/dutp/2007-2.

${ }^{47}$ Про державну службу : Закон України від 10 груд. 2015 р. № 3723-XII. Вiдомості Верховної Ради України. 2016. № 4. Ст. 43.

${ }^{48}$ Боднарчук В. Сутність і зміст поняття «компетенція» в державному управлінні. Державне управління та місцеве самоврядування. 2016. Вип. 2. С. 19-26.
} 
При визначенні компетенції місцевого самоврядування необхідно враховувати такі міркування: а) місцеве самоврядування та його органи знаходяться найближче до громадян, які мешкають на відповідній території, тому можуть швидко, конкретно, практично просто з організаційної позиції й iз найменшими витратами вирішити велику частину питань, що виникають; б) розмежовуючи предмети відання, необхідно керуватися принципом «субсидіарності», сутність якого полягає в тому, що система «питань місцевого значення» має будуватися знизу.

Компетенція органу публічної влади $є$ складною юридичною категорією, структура якої складається з предметів відання, прав та обов'язків. Вивчення компетенції іiі основних складників - не лише теоретична, а й практична проблема, оскільки системне забезпечення компетенції $\epsilon$ запорукою іiі ефективності. Необхідно ставити питання, чи зможуть органи місцевого самоврядування успішно вирішити певне завдання, використовуючи адміністративні повноваження, організаційні можливості, компетентні кадри, i тільки при отриманні негативної відповіді на ці питання доцільно передавати завдання для вирішення іншим органам ${ }^{49}$.

О. Панасюк висловив думку, що структурно компетенція - це сукупність предметів відання і повноважень. 3 метою нормального функціонування, усунення дублювання i правильного розподілу праці кожна владна інституція повинна діяти спеціалізовано, тобто в певних сферах соціальних відносин. Така сфера діяльності, у межах якої діє орган, визначається першочергово та юридично закріплюється. У юриспруденції вона дістала назву «предмети відання», під якими розуміють юридично визначені сфери соціальних відносин, у межах яких діє владний суб'єкт ${ }^{50}$.

Варто звернути увагу на позицію А. Ткаченко, який зазначив, що зміст компетенції залежить від місця, яке займає державний орган у механізмі держави, відповідно, чим вище місце займає державний орган або його посадова особа в ієрархічній системі органів державної влади, тим ширшим $\epsilon$ обсяг компетенції, яким його наділено ${ }^{51}$.

На думку М. Мазепи, компетенція визначається як предмети відання права, обов'язки й територіальні межі діяльності кожного окремого органу; як функції та конкретні повноваження (права й обов'язки) щодо визначених предметів відання; як закріплена сукупність завдань, функцій, прав та

\footnotetext{
49 Тулик I.I. Визначення терміна «компетенція» в місцевому самоврядуванні через призму основних нормативно-правових документів та принципів. Науковий вісник Ужгородського національного університету. Серія «Право». 2016. Вип. 38 (1). С. 58, 60-62.

${ }_{50}$ Панасюк О.А. До питання про співвідношення понять «повноваження» та «компетенція» суду в кримінальному провадженні. Публічне право. 2013. № 4 (12). С. 284.

${ }_{51}$ Ткаченко О.А. Поняття компетенції державного органу. Часопис Київського університету права. 2009. № 4. C. 193.
} 
обов'язків; як зміст та обсяг владних правомочностей, які має орган, а також та або інша посадова особа та які фіксуються у відповідному юридичному документі; як правова категорія, що містить у собі предмети відання й владні повноваження, визначена Конституцією й законами України, має внутрішню єдність та узгодженість ${ }^{52}$.

Узагальнюючи такі категорії, як «повноваження», «юридичні права й обов'язки», зазначимо, що їх необхідно розглядати як невід'ємні елементи компетенції. Крім цього, варто підкреслити, що компетенція як самостійне правове явище розкриває власну сутність через реалізацію повноважень, прав та обов'язків.

Наведені вище точки зору науковців дають змогу зробити висновок, що причиною їхніх розбіжностей $\epsilon$ різні підходи до визначення елементів компетенції, які становлять це поняття.

Під компетенцією (лат. competentio, від compete - взаємно прагну, відповідаю, підходжу) розуміють сукупність юридично встановлених функцій i повноважень органу державної влади, органу місцевого самоврядування або посадової особи стосовно предметів їх відання. Компетенція визначається місцем суб'єкта в системі органів державної влади й органів місцевого самоврядування. Нормативно-правовою основою компетенції $\epsilon$ конституція, конституційні та звичайні закони, статути, положення й інші правові акти. При встановленні компетенції органу влади чи посадової особи в конституції та інших нормативно-правових актах не завжди чітко розмежовуються функції та повноваження. Функції визначають напрями, сфери дії органу влади чи посадової особи, тоді як повноваження - це їхні права й обов'язки, згідно з якими визначено, що вони можуть або мають робити стосовно конкретного предмета відання.

Ю. Тихомиров визначає компетенцію як законно покладений на уповноваженого суб'єкта обсяг публічних справ. Складне явище «компетенція», на думку вченого, складається 3 елементів подвійної природи. До власне компетенційних елементів, на думку Ю. Тихомирова, належать нормативно встановлені цілі як спосіб тривалої нормативної орієнтації суб'єктів права та діяльність, спрямована на досягнення цих цілей, предмети відання як юридично визначені сфери й об'єкти впливу, владні повноваження як гарантований законом захід прийняття рішень i виконання дій. Супутнім елементом $€$ відповідальність за їх невиконання або, іншими словами, гарантії виконання компетенції ${ }^{53}$. У радянській юридичній літературі вказувалося, що «повноваження завжди предметні»

\footnotetext{
52 Мазепа М.М. Компетенція та повноваження Державної служби охорони при МВС України. Вісник Харківського національного університету внутрішніх справ. 2011. № 3. С. 206.

53 Тихомиров Ю.А. Теория компетенции. Журнал российского права. 2000. № 10. С. 55-66.
} 
та що повноваження не повністю характеризують компетенцію. У теорії права під повноваженнями розуміють вид і міру владного впливу посадової особи або державного органу на заінтересованого учасника правовідносин з метою задоволення його законного інтересу, досягнення певного соціально корисного результату.

Компетенція є складним збірним поняттям, у науковій літературі й законодавстві не наведено його однозначного трактування. Запропоновано визначити в законодавчому порядку термін «компетенція» як ключовий, співвідносний із поняттями «повноваження», «права й обов’язки», «правова регламентація», «функціонування», що входять до єдиної системи. Варто зазначити, що «повноваження» часто пов’язують із терміном «компетенція», оскільки в науці конституційного права компетенція висвітлюється як сукупність владних повноважень.

Як зазначає А. Венгеров, «для функціональної характеристики державного органу використовується поняття компетенції, яке означає взяте в єдності коло й обсяг повноважень та обов'язків, що належать цьому державному органу, а також предмет його відання» ${ }^{54}$.

На думку Ю. Георгієвського, «компетенція органів централізованого та територіального управління означає обсяг їх правоздатності й застосування повноважень щодо виконання завдань організаційно-правового характеру, коли необхідно застосовувати всі важелі управління» 55 .

Компетенція державного органу розглядається вченими як закріплена в законі або підзаконному акті сукупність його владних повноважень (прав та обов'язків), юридичної відповідальності й предмета відання

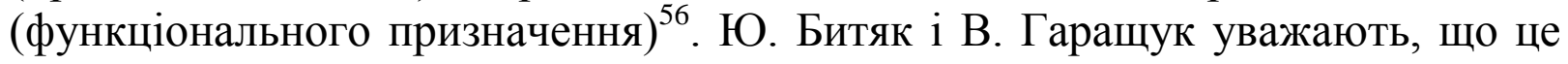
поняття означає коло справ, віднесених до відання певного державного органу, коло повноважень щодо здійснення певного виду владних дій адміністративно-розпорядчого або правоохоронного, а іноді нормоустановного характеру 57.

I. Казанчук зазначає, що «компетенція поєднує в собі два елементи: поперше, «предмети відання» (суспільні відносини); по-друге, «права й обов'язки», або «владні повноваження» органу. Така позиція більш повно визначає сутнісну характеристику компетенції, адже охоплює не тільки права й обов'язки, а й певну сферу діяльності державних органів. Не можна

\footnotetext{
54 Венгеров А.Б. Теория государства и права: учебник для юридических вузов. 2-е изд. Москва : Юриспруденция, 1999. С. 156.

55 Георгієвський Ю.В. Компетенція органів публічної влади: теорія і практика застосування. Київ : Логос, 2015. С. 83.

${ }_{56}^{56}$ Скакун О.Ф. Теорія держави і права: підручник (енциклопедичний курс). Харків : Еспада, 2006. С. 547.

${ }^{57}$ Адміністративне право України : підручник / Ю.П. Битяк, В.М. Гаращук, О.В. Дяченко та ін. ; за ред. Ю.П. Битяка. Київ : Юрінком Інтер, 2007. С. 79.
} 
встановити компетенцію будь-якого державного органу, не окресливши сферу даних йому владних повноважень, характер питань, якими він повинен займатися, оскільки ці питання (предмети відання) утворюють головний елемент компетенції органу» ${ }^{58}$.

I. Білодід визначає адміністративну компетенцію органів прокуратури як «сукупність закріплених у законодавстві повноважень державно-владного суб'єкта, що реалізуються ним у певних правовідносинах. Компетенція прокуратури поширюється на правовідносини, що виникають у сфері здійснення нагляду за дотриманням законодавства органами, які провадять оперативно-розшукову діяльність, дізнання та досудове розслідування, установами відбування покарань, іншими органами, що виконують кримінальні покарання чи застосовують заходи примусу, а також здійснення державного обвинувачення та представництва в кримінальному судочинстві у випадках, встановлених законодавством» ${ }^{59}$.

Дослідники виділяють три види компетенції прокуратури: загальна компетенція, компетенція прокуратури загалом (з можливим поділом на компетенції видів прокуратур за спеціалізацією) й індивідуальна компетенція (компетенція кожного прокурорського органу окремо). У процесі здійснення прокурорського нагляду у відносини із суб'єктами вступає конкретний прокурорський орган - це і $\epsilon$ індивідуальна компетенція. Індивідуалізація відбувається шляхом розмежування повноважень між прокурорськими органами вищого й нижчого рівня, а також між однаковими за своїм правовим становищем прокуратурами. При цьому компетенція органів прокуратури певним чином обмежена. Перше обмеження стосується кола піднаглядних суб'єктів, друге - кола актів прокурорського реагування. Класифікація повноважень прокурорів може проводитися за кількома критеріями. Так, повноваження прокурора можна розділити на види, що визначаються як основні напрями діяльності прокуратури. За цільовим призначенням повноваження прокурора поділяються на два види: основні й додаткові. Основні повноваження - це повноваження 3 виконання наглядових функцій. Своєю чергою, вони бувають предметні й функціональні.

Додаткові повноваження - це повноваження організаційного характеру (допоміжні), такі як розподіл нагляду за галузями й виконавцями, добір і розстановка кадрів тощо. I предметні, і функціональні повноваження $\epsilon$ галузевими. Загальних (єдиних) повноважень для всього нагляду не існує, усі повноваження поділяються на галузі з урахуванням специфіки кожної з них.

\footnotetext{
${ }^{58}$ Казанчук І.Д. Компетенція органів Національної поліції України щодо охорони навколишнього природного середовища та екологічної безпеки в інтеграційних умовах. Наше право. 2017. № 1. С. 55.

${ }^{59}$ Білодід I.M. Адміністративні повноваження органів прокуратури України. Науковий вісник Ужгородського національного університету. Серія «Право». 2015. ВиП. 35. Ч. ІІ. Т. 2. С. 64.
} 
Обсяг повноважень обумовлюється цілями й завданнями прокуратури. Повноважень має бути достатньо для досягнення цілей i вирішення поставлених завдань, вони мають відповідати службовим функціям. Мета діяльності прокуратури подвійна: 3 одного боку, це забезпечення законності, з іншого - охорона суб'єктивних прав громадян, юридичних осіб і держави. Окресленими цілями й визначається характер повноважень. Систему адміністративних повноважень органів прокуратури побудовано 3 урахуванням їх поділу на внутрішньоорганізаційні та зовнішньоуправлінські.

I. Білодід у дисертаційному дослідженні «Адміністративно-правовий статус органів прокуратури в умовах реформування правоохоронної системи» доходить висновку, що нині адміністративні повноваження органів прокуратури чітко не закріплені в жодному нормативно-правовому акті. Вони перераховуються разом з іншими повноваженнями. Більшість таких повноважень указано не конкретно, що зменшує ефективність управлінських процесів, дає змогу керівникам прокуратур і їх підлеглим самостійно, не завжди правильно трактувати свої права й обов'язки у сфері виконавчо-розпорядчої та наглядової діяльності» ${ }^{60}$.

Відповідно до конституційної функції прокуратури, спрямованої на забезпечення прав громадян і дотримання законності, складно однозначно визначити особливі процесуальні права прокурора. Але його діяльність у справі не можна обмежувати встановленими для осіб, які беруть у ній участь, правами, оскільки прокурор має бути наділений правом ініціювати заміну законного представника особи, коли останній не має права вести справу в суді або неналежно користується наданими йому повноваженнями, через постановлення судом окремої ухвали тощо.

Проаналізуємо структуру адміністративно-процесуальної компетенції органів прокуратури. До компетенційних елементів належать: а) нормативно встановлені цілі; б) предмети відання як юридично визначені певні сфери й об'єкти впливу; в) владні повноваження як гарантована законом міра прийняття рішень i вчинення дій. Розглянемо, як за допомогою цих елементів компетенції органів прокуратури як суб'єктів адміністративного процесу розкривається офіційний (публічний) характер їхньої діяльності, що визнається принципом адміністративного процесу. Органи прокуратури мають в адміністративному процесі чітко окреслений законом предмет відання, а саме об'єкти їхнього впливу. Щоб предмет відання міг бути повно й усебічно опрацьований тим чи іншим державним органом, останній наділяється достатніми для цього владними повноваженнями, що $€$

\footnotetext{
${ }^{60}$ Білодід I.M. Адміністративно-правовий статус органів прокуратури в умовах реформування правоохоронної системи : автореф. дис. ... канд. юрид. наук : 12.00 .07 «Адміністративне право і процес; фінансове право; інформаційне право». Харків, 2016. С. 11.
} 
гарантованою законом мірою прийняття процесуальних рішень і вчинення процесуальних дій. Під владними повноваженнями й у теорії, і в практиці кримінально-процесуальної діяльності, як правило, розуміють права державних органів, що передбачає певну свободу розсуду в їх використанні. Між тим орган дізнання, слідчий, прокурор і суд водночас наділяються й обов'язками щодо здійснення цих прав.

Адміністративний процес $є$ публічним, оскільки він здійснюється в публічних інтересах. У загальній теорії компетенції виділено одинадцять найбільш типових повноважень державного органу: 1) керувати; 2) управляти; 3) вирішувати; 4) брати участь; 5) нормувати; 6) організовувати; 7) розробляти; 3) вказувати; 9) координувати; 10) контролювати; 11) забороняти. Ці повноваження покладено на прокурора, який на різних стадіях процесу реалізує їх з урахуванням певної специфіки.

Владні повноваження $\epsilon$ головним структурним елементом адміністративно-процесуальної компетенції. Тільки це офіційне законне право сукупно із нормативно визначеними цілями і предметами відання органів $\epsilon$ підставою для того, щоб стверджувати, що той чи інший орган наділений адміністративно-процесуальною компетенцією. Інші сторони процесу (експерти, захисники) також мають цілі та предмет відання, але в них відсутні повноваження.

Доцільно зауважити, що адміністративно-процесуальна компетенція має універсальний характер. Компетенція органів прокуратури хоча й випливає 3 принципу публічності й регулюється переважно імперативними правовими нормами, але вона поширюється на суб'єктів процесу, чия поведінка визначається принципом диспозитивності й регулюється за допомогою відповідного - диспозитивного - методу ${ }^{61}$.

У зв'язку із цим потребує подальшої розробки адміністративно-правове регулювання питання про адміністративно-процесуальну компетенцію органів прокуратури України.

Однією з умов планомірного здійснення компетенції є юридичні режими, тобто спеціалізований порядок діяльності суб'єктів права для вирішення специфічних завдань або функціонування в особливих обставинах, що забезпечує стабільність діяльності структур, органів і посадових осіб. Для суб'єктів компетенції використовуються власні режими діяльності, які оформляються у вигляді регламентів, розпорядків та управлінських структур. Адміністративний розсуд розглядається як гарантована можливість вибору для прийняття правомірних рішень і вчинення дій уповноваженим суб'єктом

\footnotetext{
${ }^{61}$ Карпунцов В. Теоретичні питання формування та утвердження сучасної адміністративнопроцесуальної компетенції прокуратури України. Вісник Національної академії прокуратури України. 2018. № 1 (53). C. 7-12.
} 
у рамках його компетенції для виконання управлінських завдань. До елементів розсуду автор умовно відносить: а) адміністративно-правове веління, тобто публічний інтерес і співвіднесення 3 ним можливих дій і рішень у рамках власних повноважень; б) вироблення установки й формування відповідної мотивації; в) оцінку альтернатив юридичних дій i рішень та обгрунтування вибору; г) здійснення юридичних дій, бездіяльність, якщо воно обумовлено рівнем компетентності; д) намір і волю слідувати прийнятим рішенням, діяти в їх руслі й відповідні поведінкові акти.

Пропонується типологія адміністративного розсуду як результат комбінації його елементів і взаємодії із зовнішнім середовищем. Це розсуд проявляє себе як активно-позитивне й формується за прямими приписами закону, за дорученнями й завданнями вищестоящих органів і керівників, під тиском громадської думки, під впливом неформальних груп, 3 міркувань перестраховки тощо. Спеціальна увага приділяється такому явищу, як адміністративна патологія, ії особливостям. Підкреслюється, що деформація адміністративного розсуду породжується пробілами в законі й законодавстві та найбільш чітко виражена у сфері державного управління.

Судовий розсуд проявляється в гарантованій можливості вибору судом варіанту рішення 3 низки законних альтернатив. Принцип незалежності суддів лежить в основі легального й суб'єктивного розсуду, тобто тиск на суддів і залежність їх від влади та посадових осіб неприпустимі. Судовий розсуд висловлює особисту думку судді й формується в судовому складі як основа колективного рішення у справі. Однак системна організація судів і системні принципи встановлення їх юрисдикції зумовлюють «системну зв'язаність» судового розсуду. На думку автора, найбільш виправданими $\epsilon$ такі «способи пов'язаності», як керівні роз'яснення судової практики та інформаційно-узагальнені матеріали по категоріях справ вищих судових інстанцій. Відзначається, що в практиці Конституційного Суду сьогодні виділяється такий канал впливу, як формування його правової позиції як джерела конституційного права. Далі детально розглядаються чинники змін компетенції.

Виділяються дві форми розподілу функцій і повноважень у рамках компетенції: повна централізація, що означає, що держава здійснює всі функції управління через систему центральних органів і їх служб на місцях, a також деконцентрація, яка припускає, що здійснення всіх функцій покладається на адміністративні осередки, складники ієрархічної системи з урядовими органами нагорі. Деконцентрація також має дві форми територіальну й технічну. При територіальній формі керівники місцевих органів центрального відомства діють в межах відповідних адміністративнотериторіальних одиниць і мають певні повноваження на прийняття рішення. 
При технічній деконцентрації функцій і повноважень рішення передаються відповідальним посадовим особам, які очолюють установи й виконують спеціалізовані функції.

Важливим способом перерозподілу компетенції $\epsilon$ субсидіарність, яка виражається у двох основних постулатах: «стільки свободи, скільки можна» i «стільки суспільства, скільки можна, стільки держави, скільки необхідно». Застосовується кілька способів перерозподілу компетенції між суб'єктами як усередині їхніх систем, так і між суб'єктами, які належать до різних систем. До таких способів автор зараховує делегування повноважень від органу до органу; передачу об'єктів управління з ведення одного суб'єкта компетенції до іншого; наділення державними повноваженнями.

Детально аналізуються дві групи факторів, що негативно впливають на діяльність суб'єктів компетенції та зміщують ії в бік від нормативної моделі. До першої групи входять чинники, що проявляють себе на стадії формування, несприятливі наслідки які можна передбачити заздалегідь, до другої групи - фактори, які постійно або періодично породжують небажані відхилення фактичної діяльності суб’єктів від їх нормативної компетенційної моделі ${ }^{62}$.

Серед дослідників спостерігається велике розмаїття термінологій i досвіду застосування теорії компетенцій. Незважаючи на наочні відмінності, у всіх системах $\epsilon$ спільні моменти. Зокрема, усі системи на основі компетенцій і компетентностей використовуються як невід'ємна частина кадрової політики в процесі відбору кадрів, а також під час їх оцінки та атестації. Компетенції використовуються як інструмент для аналізу потреб у навчальній підготовці та при розробці навчальних програм.

Розроблення на основі компетенцій апарату управління вітчизняним персоналом органів державної влади й органів місцевого самоврядування $\epsilon$ пріоритетом для розвитку системи державної служби та нагальним завданням як для інститутів управління цієї системою, так і для всіх суб'єктів системи виконавчої влади.

Як правило, поняття «компетенція» вживають для об’єднання понять «предмет ведення», «функції» та «повноваження». За його допомогою описують права й обов'язки суб' єкта (як саме цей суб'єкт здійснює взаємодію) у тій чи іншій сфері, на що суб'єкт може впливати з метою виконання функцій (напрями такого впливу відповідно до цілей i завдань діяльності), які просторово-територіальні або інші встановлені межі такого впливу.

Отже, компетенція - це сукупність юридично установлених повноважень, прав та обов'язків конкретного органу чи посадової особи; визначає їх місце в системі державних органів. Юридичний зміст поняття «компетенція»

62 Тихомиров Ю.А. Теория компетенции. Журнал российского права. 2000. № 10. С. 123-124. 
включає такі елементи: предмет підпорядкування (коло об’єктів, явищ, дій, на які розповсюджуються повноваження); права й обов'язки, повноваження органа чи особи; відповідальність; відповідність поставленим цілям, завданням і функціям.

До власне компетенційних елементів належать: а) нормативно встановлені цілі, що означають спосіб тривалої нормативної орієнтації суб'єктів права та стійку діяльність із досягнення вказаних цілей. У широкому значенні маються на увазі публічні функції, без виконання яких суспільство й держава не можуть забезпечити життєдіяльність і своє існування; б) предмети відання як юридично визначені сфери й об'єкти впливу; в) владні повноваження як гарантована законом міра прийняття рішень і вчинення дій. «Супутнім» елементом $є$ відповідальність за їх невиконання. Без них компетенція втрачає публічно-правову забезпеченість за допомогою різних засобів.

В окремі історичні періоди розуміння цього терміна дещо різнилося. Зокрема, більшість із класиків, які наводилися вище, розглядали компетенцію як сукупність двох складових елементів: повноважень i предметів відання.

Більшість із радянських учених визначали компетенцію як сукупність владних повноважень та обов'язків 3 реалізації своїх функцій і цілей у межах предметів його відання.

У сучасний період значний внесок у розвиток теорії компетенції належить науковцю Ю. Тихомирову - автору фундаментальної праці «Теорія компетенції», у якій учений докладно розробив і висвітлив комплекс питань, пов'язаних із природою компетенції та iii елементами, джерелами i способами встановлення, а також велику увагу приділив характеристиці суб'єктів компетенції та проблемам динаміки компетенції - iї реалізації, перерозподілу, зміни. Особливо важливим $\epsilon$ те, що чи не вперше в пострадянський період здійснено спробу розкриття людського фактора в компетенції, продемонстровано практичні проблеми іiі динаміки реалізації, перерозподілу, змін. Надзвичайно важливими й актуальними видаються пропозиції щодо механізмів захисту компетенції, відповідальності за порушення в цій сфері, питання вирішення спорів про правомочність, що видається надзвичайно важливим при здійсненні аналізу компетенції міністра юстиції.

В англійській мові поняття компетенції сьогодні фактично прирівнюється до поняття компетентності. Практично в усіх інших європейських мовах поняття компетенції не диференціюється як ототожнене поняття, тобто компетентність і компетенція є однією лексичною одиницею. Винятком $є$ деякі країни з пострадянського простору, у лексичному апараті яких наявні 
обидва поняття. Імовірно, пострадянські країни при перекладі й ототожненні досліджуваних понять керувалися радянським підходом, відповідно до якого у вітчизняних словниках іноземних слів «компетентність» $\mathrm{i}$ «компетенція» є різними поняттями, а більшість дослідників із європейських країн слідували американському підходу, який передбачав синонімічність цих понять.

Вирішення проблеми співвідношення понять компетенція/компетентність ускладнюється й тим фактором, що на цей момент видається проблематичним установити, чим керувалися перекладачі, коли вирішили затвердити у вітчизняному просторі семантичне диференціювання слів competence i competency, які на момент появи в вітчизняній лексиці були рівнозначними поняттями в англійських та американських словниках, і закріпити за ними переклад слова competence як компетентності, а competency як компетенції.

Бути компетентним означає здатність (уміння) мобілізувати в цій ситуації здобуті знання й досвід. Звідси випливає поняття «компетенція», яке походить від латинського слова competere й позначає кваліфікацію і придатність у майбутній професійній діяльності.

Щодо визначення поняття «компетенції» немає єдиного тлумачення, у великому енциклопедичному словнику поняття компетенції трактується як коло повноважень, наданих законом, статутом або іншим актом конкретному органу або посадовій особі; знання, досвід в тій чи іншій галузі.

Словник тлумачення іноземних слів розкриває поняття «компетентний» як володіння компетенцією - колом повноважень якої-небудь установи, особи або колом справ, питань, що підлягають чиєї-небудь ведення: competent (франц.) - компетентний, competens (лат.) - відповідний, здібний, competere - вимагати, відповідати, бути придатним, competence (англ.) здатність (компетенція).

\section{ВИСНОВКИ}

У сучасній дидактиці під поняттям «компетенція» розуміють загальну здатність і готовність особистості до успішної професійно-трудової діяльності, спираючись на знання й досвід, придбаних завдяки навчанню.

У державному стандарті України визначено поняття «компетенція» як суспільно визнаний рівень знань, умінь, навичок, ставлень у певній сфері діяльності людини; тоді як компетентність - набута в процесі навчання інтегрована здатність особистості, що складається зі знань, володіти більш визначеними поглядами на сутність цього поняття. Натепер виділяється два значення цього поняття. Під першим значенням мається на увазі коло питань, повноважень, у яких конкретна людина $є$ компетентною. Під другим 
значенням компетенція виступає як сукупність знань, умінь, навичок, які необхідні для успішного виконання певної діяльності. У загальному сенсі компетентність - це, по суті, професіоналізм, а компетенції є компонентами професіоналізму, тобто тим, за рахунок чого професіоналізм формується.

Як видно з наведених вище термінологічних визначень в українських енциклопедичних і словникових виданнях, і сучасні науковці по-різному підходять до тлумачення цього терміна.

Отже, аналіз вітчизняних і зарубіжних досліджень свідчить, що сутність i зміст поняття «компетенція» потребують подальшого уточнення в контексті реформування системи державного управління. Насамперед це стосується відповідності повноважень завданням, що будуть покладені на оновлений інститут державного управління, і відповідальності державних інституцій і державних службовців. Однак уже сьогодні можна стверджувати, що під час формування компетенції в системі державного управління має бути врахований іiі зв'язок із компетентністю та професіоналізмом осіб, які будуть нею володіти.

\section{АНОТАЦІЯ}

Серед науковців щодо трактування понять «компетенція» та «компетентність» у сучасній правовій науці немає єдиної думки, а також відсутні загальноприйняті дефініції цих термінів, що підкреслює важливість і необхідність дослідження зазначеної проблематики.

Зазначено, що правильному розумінню компетенції сприяє іiі загальноправове трактування, яке $\epsilon$ базовим поняттям публічного права, що визначає життєдіяльність не тільки суб'єктів публічно-правових, а й приватноправових відносин. Воно визнається й установлюється передусім нормами конституційного, адміністративного, фінансового, кримінального та міжнародного публічного права.

Визначено, що предмет відання як структурний елемент категорії компетенція є способом юридичного зазначення тих сфер місцевого життя, які визначаються як предмет дій органу місцевого самоврядування.

Визначення та реалізація компетенцій органів публічної влади за предметною ознакою базується за предметами відання, утвердженими в нормативному полі, на основі яких відбувається визначення повноважень, тобто прав та обов'язків. Звернено увагу на предметний складник у компетенції органів публічної влади, яка знаходиться в площині визначення та закріплення предметів відання. Передумовою до формування предметної компетенції $€$ загальна компетенція, що зазвичай визначається на конституційному рівні або/та законами. 


\section{ЛІТЕРАТУРА}

1. Лазарев Б.М. Компетенция органов управления. Москва : Юрид. лит., $1972.280 \mathrm{c}$.

2. Бахрах Д.И. Административное право России : учебник для вузов. Москва : Изд. группа НОРМА-ИНФРА-М., 2000. 640 с.

3. Батракова Д. Визначення компетенції місцевих органів державної влади та органів місцевого самоврядування: проблема співвідношення. Юридичний вісник. 2016. № 1. С. 17-21.

4. Кутафин О.Е., Шеремат К.Ф. Компетенция местных органов : учебное пособие. Москва, 1996. 224 с.

5. Кравченко В.В., Пітник М.В. Конституційні засади місцевого самоврядування в Україні (основи муніципального права) : навчальний посібник. Київ, 2001. 176 с.

6. Потьомкіна Ю.С. Компетенція як ключове поняття для управління персоналом у системі державної служби. Економіка та держава. 2013. № 4. C. $132-134$.

7. Кулакова Є.В. Поняття та елементи господарської компетенції обласних рад та обласних державних адміністрацій. Науковий вісник Міжнародного гуманітарного університету. Серія «Юриспруденція». 2013. Вип. 6-2 (2). С. 19-23.

8. Кобзар Н.В. Поняття «компетентність», «компетенція» і «готовність до діяльності» в сучасній освітній парадигмі. Науковий вісник Донбасу. 2010. № 3. C. 12-17.

9. Клепко С.Ф. Філософія освіти в Європейському контексті. Полтава : ПОІППО, 2006. $328 \mathrm{c}$.

10. Бояцис Р. Компетентный менеджер. Модель эффективной работы / пер. с анг. Москва : ГИППО, 2008. 352 с.

11. Лайл М., Спенсер. Компетентность на работе. Модели максимальной эффективности / пер. с англ. Москва : НІРРО. 2005. 384 с.

12. Равен Дж. Компетентность в современном обществе: выявление, развитие и реализация / пер. с англ. Москва : Когито-Центр, 2002. 396 с.

13. Бібік Н. Компетентнісний підхід презентації освітніх результатів. Школа першого ступеня: теорія $і$ практика : зб. наук. пр. ПереяславХмельницького держ пед. ун-ту ім. Григорія Сковороди. ПереяславХмельницький, 2004. Вип. 10. 196 с.

14. Великий тлумачний словник сучасної української мови / уклад. і гол. ред. В.Т. Бусел. Київ, Ірпінь : ВТФ «Перун», 2001. 144 с.

15. Словарь иностранных слов. 14-е изд., испр. Москва : Рус. яз., 1987. $608 \mathrm{c}$. 
16. Компетентнісний підхід у сучасній освіті: світовий досвід та українські перспективи: Бібліотека з освітньої політики / за заг. ред. О.В. Овчарук. Київ : K.I.C., 2004. $112 \mathrm{c.}$

17. Борисов П.П. Компетентностно-деятельностный подход и модернизация содержания общего образования. Стандарть $и$ мониторинг в образовании. 2003. № 1.

18. Краевский В.В. Предметное и общепредметное в образовательных стандартах. Педагогика. 2003. № 2.

19. Хуторской А.В. Ключевые компетенции как компонент личностноориентированной парадигмы образования. Народное образование. 2003. № 2 . № 3 .

20. Шишов С.Е. Понятие компетенции в контексте качества образования. Стандарт и мониторинг в образовании. 1999. № 2.

21. Стратегія реформування освіти в Україні : рекомендації з освітньої політики. Київ : К.І.С., 2003. 296 с.

22. Васильева Л.Н. Взаимоотношения федеральных и региональных органов государственной власти: пути совершенствования. Журнал российского права. 2000. № 8.

23. Тихомиров Ю.А. Теория компетенции. Журнал российского права. 2000. № 10. C. 22-32.

24. Словарь иностранных слов. 18-е изд., стер. Москва : Рус. яз., 1989. 624 с.

25. Словник іншомовних слів / за ред. О.С. Мельничука ; головна ред. Української радянської енциклопедії Академії наук Української РСР (АН УРСР). Київ : АН УРСР, 1974. 781 с.

26. Малиновський В.Я. Словник термінів і понять 3 державного управління. вид. 2-ге, допов. і виправл. Київ : Центр сприяння інституц. розвитку держ. служби, 2005. 254 с.

27. Скакун О.Ф. Теорія держави і права : підручник / пер. 3 рос. Харків : Консум, 2001. 655 с.

28. Карпа М.I. Визначення предметів відання як складових компетенцій органів місцевого самоврядування. Публічне управління: иіннісні орієнтири, стандарти якості та оцінка ефективності : матеріали Всеукраїнської наук.-практ. конференції за міжнар. участю (м. Київ, 26 травня 2017) / Національна академія державного управління при Президентові України. Київ, 2017. 256 с.

29. Батанов О. Проблеми конституційної регламентації компетенції місцевого самоврядування в Україні та зарубіжних країна. Право України. 2015. № 9. C. 104-112. 
30. Сушинський O.I. Компетенція держави та місцевого самоврядування у сфері комунальних послуг: концепція та практика : монографія. Львів : ЛРІДУ НАДУ, 2005. 156 с.

31. Сушинський O.I. Місцеві державні адміністрації: статус і організація діяльності : монографія. Львів : ЛРІДУ НАДУ, 2012. 82 с.

32. Сушинський O.I. Правоохоронні органи України: проблемні аспекти статусу : монографія. Львів : Львівський державний інститут новітніх технологій та управління імені В'ячеслава Чорновола, 2010. 248 с.

33. Сушинський O.I. Юридична відповідальність у контексті демократизації публічної влади. Демократичні засади державного управління та адміністративне право : монографія / кол. авт.: Ю.С. Шемшученко, В.Б. Авер'янов, О.Ф. Андрійко та ін. ; за заг. ред. д. ю. н. В.Б. Авер'янова. Київ : Юридична думка, 2010. С. 300-306.

34. Рябовол Л.Т. Правова предметна компетентність: поняття, структура, правові предметні компетенції. Наукові записки КДПУ. Серія «Педагогічні науки» / ред. кол. : В.В. Радул та ін. Кіровоград : КДПУ ім. В. Винниченка, 2013. Вип. 121. Ч. 2. С. 263-268.

35. Кушнір І.П. Проблемні питання відомчої нормотворчої компетенції прикордонної служби України. Молодіжний науковий юридичний форум : матеріали Всеукраїнської науково-практичної конференції до Дня науки, м. Київ, Національний авіаційний університет, 18 травня 2017 р. Тернопіль : Вектор, 2017. Том 1. 356 с.

36. Конституція України: прийнята на п'ятій сесії Верховної Ради України 28.06.1996. Відомості Верховної Ради Украӥни. 1996. №30. Ст. 141.

37. Майстро С.В. Розмежування повноважень органів державної влади та органів місцевого самоврядування. Державне будівництво. 2012. № 1. URL: http://nbuv.gov.ua/UJRN/DeBu_2012_1_33.

38. Карпа М. Предметна компетенція органів публічної влади. Актуальні проблеми державного управління. 2017. Вип. 3. С. 50-56.

39. Недашківська Т. Професійність державних службовців: компетентнісний підхід. Наук. пр. Наи. акад. держ. упр. при Президентові України / редкол. : О.Ю. Оболенський (голов. ред.), С.В. Сьомій та ін. Київ : Вид-во НАДУ, 2008. Вип. 1. С. 65-74.

40. Тихомиров Ю. А. Современное публичное право : монограф. учеб. / Ин-т законодательства и сравнительного правоведения при Правительстве Российской Федерации. Москва : ЭКСМО, 2008. 446 с.

41. Лазор О.Я. Хорошенюк О.В. Публічна служба в Україні: компетенції та повноваження (Частина II) : монографія. Хмельницький : Вид-во ХГПА, 2009. $440 \mathrm{c}$. 
42. Гогіна Л. Компетенції та компетентності в державній службі України: до проблеми понятійного апарату. Державне управління: теорія та практика: електрон. наук. фах. вид. / редкол. : С.В. Сьомій (голов. ред.), В.М. Князев та ін. Київ : Вид-во НАДУ 2007. № 2 (6). URL: www.nbuv.gov.ua/ e-journals/dutp/2007-2.

43. Великий енциклопедичний юридичний словник / за ред. акад. НАН України Ю.С. Шемшученка. Київ : Юрид. думка, 2007. 992 с.

44. Про державну службу : Закон України від 10 груд. 2015 р. № 3723-XII. Відомості Верховної Ради Украӥни. 2016. № 4. Ст. 43.

45. Боднарчук В. Сутність і зміст поняття «компетенція» в державному управлінні. Державне управління та місиеве самоврядування. 2016. Вип. 2. C. $19-26$.

46. Тулик I.I. Визначення терміна «компетенція» в місцевому самоврядуванні через призму основних нормативно-правових документів та принципів. Науковий вісник Ужгородського національного університету. Серія «Право». 2016. Вип. 38 (1). С. 59-62.

47. Панасюк О.А. До питання про співвідношення понять «повноваження» та «компетенція» суду в кримінальному провадженні. Публічне право. 2013. № 4 (12). C. 282-290.

48. Ткаченко О.А. Поняття компетенції державного органу. Часопис Київського університету права. 2009. № 4. С. 192-197.

49. Мазепа М.M. Компетенція та повноваження Державної служби охорони при МВС України. Вісник Харківського нащіонального університету внутрішніх справ. 2011. № 3. С. 202-210.

50. Венгеров А.Б. Теория государства и права: учебник для юридических вузов. 2-е изд. Москва : Юриспруденция, 1999. 528 с.

51. Георгієвський Ю.В. Компетенція органів публічної влади: теорія i практика застосування. Київ : Логос, 2015. 345 с.

52. Скакун О.Ф. Теорія держави і права : підручник (енциклопедичний курс). Харків : Еспада, 2006. 776 с.

53. Адміністративне право України : підручник / за ред. Ю.П. Битяка. Київ : Юрінком Інтер, 2007. 544 с.

54. Казанчук І.Д. Компетенція органів Національної поліції України щодо охорони навколишнього природного середовища та екологічної безпеки в інтеграційних умовах. Наше право. 2017. № 1. С. 54-61.

55. Білодід I.M. Адміністративні повноваження органів прокуратури України. Науковий вісник Ужггородського наиіонального університету. Серія «Право». 2015. Вип. 35. Ч. II. Т. 2. С. 63-67.

56. Білодід I.М. Адміністративно-правовий статус органів прокуратури в умовах реформування правоохоронної системи : автореф. дис. ... канд. 
юрид. наук : 12.00.07 «Адміністративне право і процес; фінансове право; інформаційне право». Харків, 2016. 22 с.

57. Карпунцов В. Теоретичні питання формування та утвердження сучасної адміністративно-процесуальної компетенції прокуратури України. Вісник Національної академії прокуратури України. 2018. № 1 (53). С. 5-13.

Information about authors:

Borshchevskyi I. V.,

Candidate of Law, Associate Professor, Associate Professor at the Department of General Legal Disciplines and International Law

Odesa I. I. Mechnikov National University 2, Dvoryanska str., Odesa, 65000, Ukraine

Hryn O. D.,

Candidate of Law, Associate Professor, Associate Professor at the Department of General Legal Disciplines and International Law

Odesa I. I. Mechnikov National University 2, Dvoryanska str., Odesa, 65000, Ukraine 